\title{
Disability in Sport It's Our Time: From the Sidelines to the Frontlines (Title IX-B)
}

\author{
Ted Fay \\ SUNY Cortland
}

This paper is based, in large part, on remarks expressed by the author in the concluding keynote address at the 2011 NCAA Scholarly Colloquium held at the Grand Hyatt Hotel in San Antonio, TX on January 12, 2011. Special thanks are to my colleague, Dr. Richard Southall of the University of North Carolina for nominating me for this keynote speech entitled Disability and Sports and to both Dr. Jan Boxill of the University of North Carolina and Dr. Scott Kretchmar of Penn State University, as well as members of the NCAA Colloquium and Journal of Intercollegiate Sport Editorial Board who very kindly extended the invitation. It has been 12 years since I completed Race, gender, and disability: A new paradigm toward full participation and equal opportunity in sport (Fay, 1999) as my doctoral dissertation at the University of Massachusetts-Amherst. At the time, it was one of the first scholarly works that intentionally connected the issues of social justice, prejudice and discrimination for individuals with a disability as being similar to related issues based on race and gender. Since 1999, a number of academics and advocates have begun to address pervasive marginalization of athletes with a disability in sport from the perspective of fairness, equity and universal human rights.

This keynote at the 2011 Colloquium represented one of the first times that interconnections of race, gender and disability had been intentionally and consciously linked together as the major of themes or threads on social justice in sport at a national conference. It was a special honor to be asked to present the subject of social justice as related to the topic of disability in sports. Specifically, it was both humbling and a rare privilege to have been able to share the stage at the 2011 Colloquium with fellow keynote speakers Dr. Allen Slack, Dr. Harry Edwards and Dr. Susan Cahn along with the invited expert panelists for each keynote session. Each of these individuals are nationally and internationally recognized scholars in their respective fields and whose body of work focuses mainly on issues related to race and gender. It is also important to note that these academics, along with members that participated in the 2011 NCAA Colloquium, represent a broad set of disciplines ranging from management to law to sociology to history and philosophy. The uniting themes of social justice, prejudice and discrimination and the topics presented in my address and in this article are intended to reflect a number of timely

Fay is with Sport Management, State University of New York at Cortland. 
and complex policy and legal issues facing sport governing bodies in how to view, understand, integrate and provide inclusion for athletes with a disability. In so doing, the critical contexts of marginalization (Current Status Quo) as contrasted by legitimatization (New Inclusive Paradigm) will be examined.

As already stated, this article is about challenging the persistent prejudice and discrimination of a group of athletes who are largely invisible and often marginalized institutionally-based varsity sport environments of the nation's high schools, colleges and universities. The NCAA and its member institutions have been forced to deal with issues of social justice and inequality regarding race (e.g., Civil Rights Act of 1964) and gender (e.g., Title IX of the Educational Reform Act of 1972) for much of the last half century. Like many other sport governing bodies, however, the NCAA and its member institutions have continuously failed to adequately address the social inequality of the profound lack of opportunities for aspiring athletes with a disability of college age (e.g., the Rehabilitation Act of 1973; Americans with Disabilities Act of 1990).

This is not surprising given the propensity for national and international sport governing bodies to continue to fail to see the urgency of this issue as critical to them. Often sport governing bodies within the United States such as each of the 50 state high school athletic associations, the various college sport leagues and conferences, as well as national umbrella organizations like the National Federation of State High School Associations (NFSHSA); the National Junior College Athletic Association (NJCAA), the National Association of Intercollegiate Athletics (NAIA); the National Intercollegiate Sport \& Recreation Association (NISRA), and the National Collegiate Athletic Association (NCAA) with its 130 affiliated leagues and conferences made up by its nearly 1300 member institutions spread across three Divisions have both consciously and unconsciously helped to perpetuate the false premise that separate, segregated opportunities for sport, leisure and cultural activities by persons with a disability are both desirable and equitable (ncaa.org).

The author, along with colleagues, Eli Wolff of the Watson Center of International Studies at Brown University and Dr. Mary Hums of the University of Louisville, cofounded the Disability in Sport Initiative (Initiative) over ten years ago at the Center for the Study of Sport in Society at Northeastern University from the period of 1999-2010. The Initiative, which is now located at Brown University's Watson Center for International Studies, was intentionally created for the purpose of creating a broader dialogue within all aspects and levels of society (e.g.,., local, regional, national and international) to add a discourse of "ableism" to the ongoing social justice issues as related to racism and sexism as found in sport and in society. The activism and advocacy necessary to advance greater access, inclusion, equality, respect, legitimacy and opportunity for people with disabilities in sport and in society is no different than on the same effort needed to combat persistent racism and sexism.

\section{Purpose of Study}

As of January 12, 2011, the tenet of "separate, but equal" promulgated originally in the Supreme Court case of Plessy v. Ferguson in 1896 and providing the legal basis for the constitutionality of state laws in the former Confederate states that required institutionalized racial segregation and prejudice in both public and private 
businesses in the former Confederate states of the U.S. South (Plessy v. Ferguson, 1896). The legacies of injustice fostered during this era of Jim Crow is now likely to be totally unacceptable in any public discussions of race and gender in U.S. society as well as in sport. This keynote and article are on the near convergent anniversaries of the 50th Anniversary of the Freedom Rides of 1961 that protested the blatant racial injustice of a half century of Jim Crow practices in the South, of the nearing of the 40th Anniversaries of Title IX that changed gender inequality in schools, universities and sport for women and the Rehab Act of 1973 which radically changed access to public education and other basic rights for children with disabilities to the just completed 20th Anniversary of the Americans with Disabilities Act of 1990, we still witness blatant prejudice and discrimination in society and in sport for individuals with disabilities.

The bottom line is that despite the enactment of public law and policies that have facilitated some very modest gains over the past 40 years, young men and women with disabilities are still marginalized and routinely excluded from the most basic of opportunities to engage in sport, recreation, leisure and physical activities (Fay \& Wolff, 2009; Lakowski, 2009; and Lord \& Stein, 2009). As a two-sport NCAA varsity athlete in both football and lacrosse who over 40years ago sustained career-ending multiple knee, body and head injuries, this topic resonates as not just as something I have studied and written about, but something I have lived as a victim, as an activist, as a scholar and as an advocate. The aim of this article is to present a critical perspective regarding the status of the inclusion of athletes with disabilities within college sports on the near 40th Anniversary of Title IX passed by Congress in 1972 and the just passed 20th Anniversary commemorating the passage of the Americans with Disabilities Act enacted in 1990. This article builds upon the conceptualization of the "Dynamics of Inequality" as illustrated by George Sage in his book, Power and Ideology in American Sports (1998, p. 59) (Fig. 1).

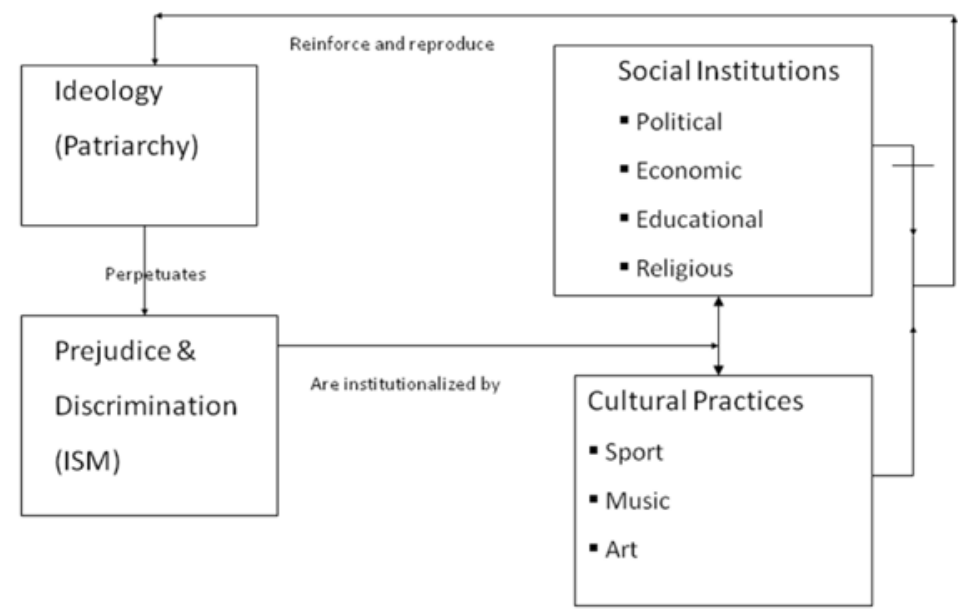

Figure 1 - Social Dynamics of Inequality 
This presentation uses a rights-based approach to social justice that incorporates a historical framework and is grounded in distributive justice, critical social theories (e.g., race, gender, and disability), combined with the open systems theory of management. In so doing, relevant social policies, regulations and case law will be discussed that inform the broader social context of this debate. An understanding the commonalities of inequality facing each of these three protected classes as based on race, gender and disability from the so-called three legs of a stool upon which the on-going hegemony of white, male, able-bodied privilege sits.

The common inequalities of ghettoizing, segregating schools and public facilities, stigmatizing based on commonly accepted labeling language within society that leads to an overall gestalt of marginalization. This also results in a set of inculcated cultural beliefs that create a set of dichotomies of prejudice \& discrimination based on race, gender and/or disability that can be framed as: a) cultural versus legal, b) majority versus minority, c) professional versus personal, d) explicit versus implicit, and e) convenient versus right (Fay, 2005). By using this type of viewing lens, relevant social policies, regulations and case law are critical to informing the broader social context of this debate (Coakley, 2008). The contention of this paper is that equity in the context of sport is a major life activity and therefore is a universal human right and not a privilege (CPR, 2007, Lord \& Stein, 2009). Given this perspective, equity is framed and defined in a spectrum a legal, civil and social right (Lord \& Stein, 2009; Lakowski, 2009).

\section{Critical Change Factors Model}

In his work Race, Gender, and Disability: A New Paradigm Toward Full Participation and Equal Opportunity in Sport Fay (1999), the author established a new theoretical framework entitled the Critical Change Factors Model (CCFM) (Fig 2) to serve as a coding structure to be able to bring a large field of data under some level of control, coherence, and readability, thus minimizing the potential bias or a given researcher or analyst. The set of ten core factors is drawn from equity (including distributive and participatory justice), critical social (including agency), and open-systems theories. The prevailing logic behind the creation and selection of these specific principles was one of commonality or universality, rather than uniqueness to a specific identity group (e.g., race, gender, or disability), organization (e.g., the leagues and conferences, the NCAA, or a sport governing body). These factors were used initially to determine differences in breakthroughs and progression toward inclusion at three primary stratification levels of (a) athletes, (b) coaches and middle-level management, and (c) senior executive or ownership of organization and/or franchise (Fay, 1999, Fay \& Wolff, 2009). The model also provides a weighting scheme for each factor into one of four categories.

Three meta-case studies were presented related to the historical struggles for integration, inclusion and equity of blacks in Major League Baseball with comparison with the similar struggles of women into intercollegiate sport in America to the additional perspectives based on issues of disability in sport. Inclusion of adaptive sports as recognized varsity sports with corresponding NCAA Championships would represent a major paradigm shift that would be likely need to be facilitated by many of the above ten critical change factors. 


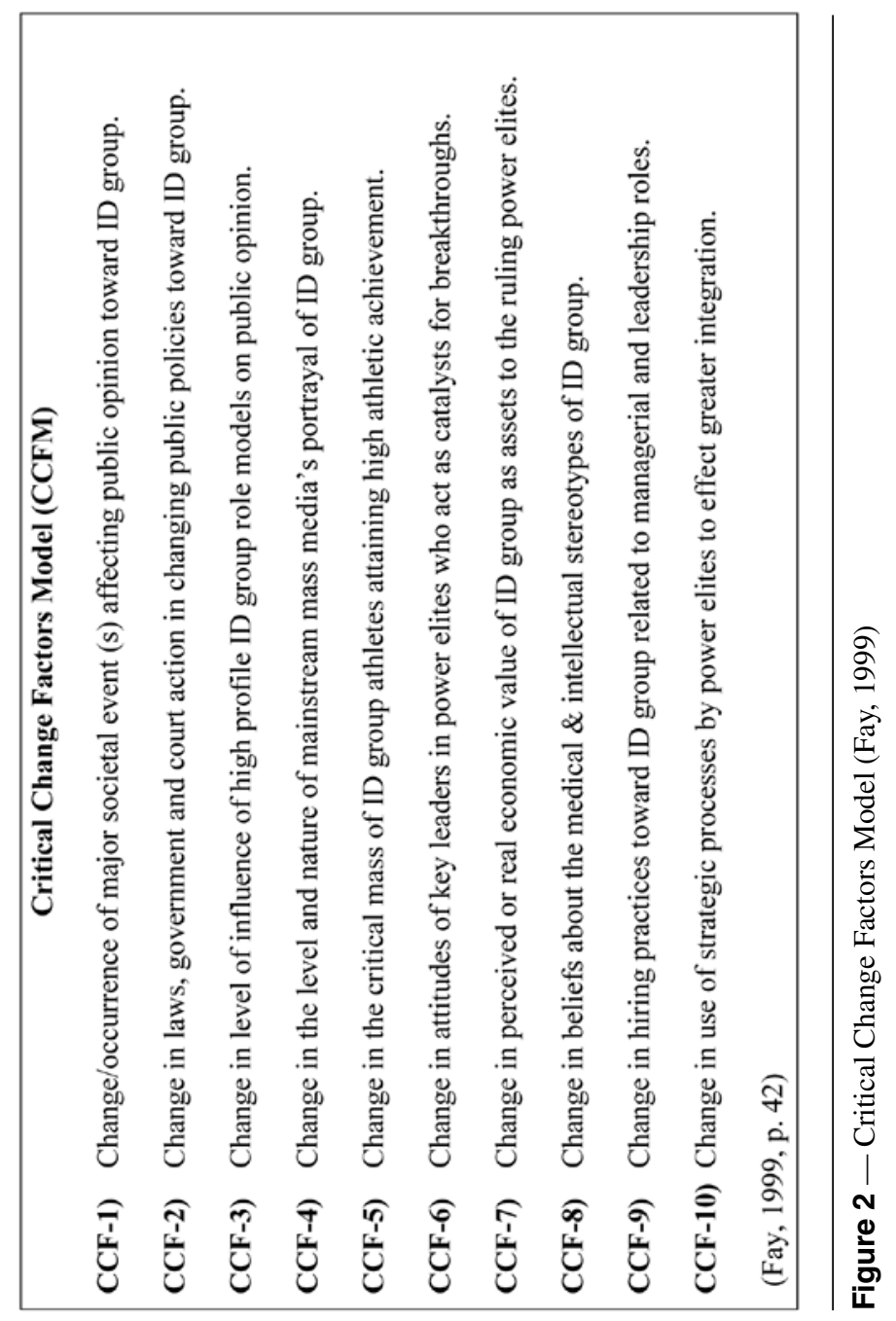


- Category I-CCF is sufficient by itself to cause change;

- Category II-CCF is necessary but not sufficient by itself to cause change;

- Category III-CCF is supportive but not necessary or sufficient by itself to cause change

- Category IV-CCF is counter-productive because it causes a reversal or regression to increased integration and inclusion of an identity group (Fay, 1999, 2009).

The question is which of the ten CCF factors fall into either Categories I or II, thus meaning they would be necessary to help cause a change in the status of athletes with disabilities as new varsity athletes participating in NCAA member institutions. No factor was identified as a Category I as being sufficient by itself to cause this change. Correspondingly, CCF Factors F1-F6 were identified as falling into Categories II as being necessary, but not sufficient by themselves to cause change. CCF Factors F7-F10, were identified as Category III level factors which mean they would be supportive but not necessary or sufficient by themselves to cause change

The first factor that has been identified as relevant as a Category II factor is F1 due to societal reaction to returning Iraqi and Afghan war veterans. The impact of war and major changes within all branches of the United States military relative to the prevailing attitudes of prejudice and discrimination, policies and laws in society of the times regarding African-Americans, women and veterans with a disability have been well chronicled. Dating back to World War II (1941-1945), African-Americans and women military personnel forced changes in widespread practices and policies of discrimination. The Korean War (1951-was the first ever fought by an "officially integrated" U.S. military based on race. More recently the Viet Nam War (1963-1975), the Persian Gulf War (1990-1991); the Iraq War (2003-2010) and finally the current conflict in Afghanistan (2001—present) have witnessed significant changes regarding public attitudes toward veterans with a disability.

\section{Definitions}

Before moving forward into the examining the legal and regulatory environments that have changed over the past half century, one must set a foundation of definitions from which one can build a common language for further discussion as related to the term disability and ableism (e.g., racism or sexism). This brief section provides a set of related definitions that have been selected and used intentionally by the author to help the reader to better understand and describe diverse elements of this paper.

\section{Definition of Disability (ADA, 1990):}

An individual meets the definition of having a disability under the Rehab Act and ADA if he/she has: a) a physical or mental impairment that substantially limits one or more major life activities, b) a record of such an impairment; or being regarded as having such an impairment. 


\section{Definition of Impairment:}

Factors involved in determining whether an individual is substantially limited in a major life activity:

i. The nature and severity of the impairment

ii. The duration or expected duration of the impairment, and

iii. The permanent or long term impact, or the expected permanent or long term impact of or resulting from the impairment."

\section{Definition of Impairment-Mental Disability:}

A definition of a mental impairment may include "any mental or psychological disorder, such as mental retardation, organic brain syndrome, emotional or mental illness, and specific learning disabilities."

\section{Definition of "Substantially Limits" is further defined in the Rehab Act and ADA to mean:}

1) Unable to perform a major life activity that the average person in the general population can perform; or

2) Significantly restricted ass to the condition, manner or duration under which an individual can perform a particular major life activity as compared with the condition, manner, or duration under which the average person in the general population can perform the same major life activity.

\section{Definition of a Major Life Activity (ADA, 1990):}

Major life activities include "functions such as caring for one self, performing manual tasks, walking, seeing, hearing, speaking, breathing, learning, and working."

Adding to these definitions related to the term disability as defined by the Americans with Disabilities Act (1990) are two additional definitions of "ableism" and "internalized ableism" that help provide clearer relationship and parallel to racism and sexism.

\section{Definition of Ableism:}

"the devaluation of disability" that "results in societal attitudes that uncritically assert that it is better for a child to walk than roll, speak than sign, read print than read Braille, spell independently than use a spell-check, and hang out with non-disabled kids as opposed to other disabled kids." (Hehir, 2002)

\section{Internalized Ableism:}

"Ableism devalues people with disabilities and results in segregation, social isolation and social policies that limit their opportunities for full societal participation. Unfortunately, persons with disabilities are also susceptible to 
internalizing stereotypes and negative beliefs. This process which we call internalized ableism is similar to internalized racism and sexism of other devalued people." (Mackelprang and Salsgiver, 1999).

This paper builds upon the following five main hypotheses.

\section{Hypotheses}

1. Individuals with disabilities within the United States are viewed by society, as reinforced through public law, regulation and a history of case law, as having only a privilege and not an inalienable human right to participate in sport, recreation, leisure and play.

2. Individuals with disabilities within the United States have very limited opportunities to participate in youth, scholastic and intercollegiate athletics as compared with their peers who are identified and labeled by society as ablebodied due to lack of regulatory guidelines pertaining to this inclusion as a right and not a privilege.

3. Individuals with disabilities often reinforce and accept the disparity in sport opportunities in scholastic and intercollegiate athletics, as compared with their peers who are identified and labeled by society as able-bodied, through an acculturation process defined as "internalized ableism."

4. Sport governance systems use a medical pathology model as a means to preclude individuals with disabilities within the United States from participating in scholastic and intercollegiate athletics based on a medical justification principle of health and safety of perceived harm to the individual as well as to fellow competitors.

5. Sport governance systems use socially constructed classification systems and eligibility criteria, as well as performance standards, as a means to control and/or preclude individuals with disabilities within the United States from participating in scholastic and intercollegiate athletics based on the principle that this participation is a privilege and not a right.

\section{CCF-2: A Policy Framework of Selected Laws Dealing with Athletes with a Disability}

It is valuable to understand and correlate major policy and regulatory frameworks over the past 50 years that have direct or significant indirect bearing on the conditions in the United States with respect to integration and inclusion in society as related to individuals with a disability who are either aspiring or accomplished athletes. The advocacy and activism which resulted from various wars (CCF- 1) was vital in continually pushing for societal change which as represented in the second factor $\mathrm{CCF}-2$ which resulted in new federal and state laws, government regulations and a series of court actions necessary to change and sustain a reduction in prejudice and discrimination toward African-Americans, women and people with a disability (Fay, 1999; Coakley, 2008). The following are two outlines of timelines and short descriptions of key federal policies and regulatory actions from 1972 until the pres- 
ent that either impact people with disabilities directly or have a significant indirect impact. The second framework that follows provides a brief listing and scope of relevant case law that has had a huge bearing on the interpretation and differentiation of what is a right and what remains only a privilege to athletes with a disability in their quest for full integration and respect within mainstream sport opportunities.

\section{Title IX-1972}

"No person in the United States shall, on the basis of sex, be excluded from participation in, be denied the benefits of, or be subjected to discrimination under any educational program or activity receiving Federal financial assistance."-United States Congress, 1972.

In Title IX's nearly 40 year history the impacts on female athlete participation have been significant including an increase of female athletic participation at the high school level by $904 \%$ (From 1 in 27 girls to 1 in 2.5 girls) and a corresponding increase at the college/university level by $456 \%$. The three part tests for Title IX compliance requires that institutions have to use any one of the following options: 1) Proportionality between male and female athletes, or 2) demonstrate a history and continued practice of by the respective institution expanding opportunities for the underrepresented gender, or 3) demonstrate having fully met the interests and abilities of the underrepresented gender. Athletic scholarship opportunities are the only dollar-for-dollar requirement under Title IX. Thus scholarship dollars and the total scholarship budget must be proportional to participation of male and female athletes (Lakowski, 2009).

\section{The Rehab Act of 1973}

"No other qualified individual with a disability in the United States shall, on the basis of disability, be excluded from participation in, be denied the benefits of, or be subjected to discrimination under any educational program or activity receiving Federal financial assistance.”-United States Congress, 1973

"A recipient that offers physical education courses or that operates or sponsors interscholastic, club, or intramural athletics shall provide to qualified handicapped students an equal opportunity for participation."

The clause in the Educational Reform Act of 1972 set of a series of shock waves through both interscholastic and intercollegiate athletics in the United States because it attempted to rebalance a very unbalanced equity paradigm between boys and girls and young men and women. It is an important parallel to what could have, but did not happen one year later with the Rehabilitation Act of 1973. The following brief description of Title IX is provided to contrast the absence of a parallel structure a set of conditions in the Rehab Act of 1973. Title IX was intended to redress the inequities with boys and men based on the following three basic provisions: 1) Participation Opportunities that provides effective accommodation of student interests and abilities, 2) Athletic Financial Assistance that includes end of year high school scholarship awards as well as college athletic scholarship awards, and 3) Equal treatment/benefits that are described as "all" other program components, 
also known as the "Laundry List" as presented in Terri Lakowski's article; Athletes with disabilities in school sports: a critical assessment of the state of sports opportunities for students with a disability (Lakowski, 2009).

\section{Amateur Sports Act of 1978}

The Amateur Sports Act of 1978 set up the governance structure for amateur sports in the United States. The U.S. Olympic Committee (USOC) was charged with governing amateur sports and in turn, authorized one national governing body (NGB) to govern each specific sport. This charge included making the rules, choosing teams for international competitions, certifying officials, running national championships, and also developing a given sport from the grassroots level through Olympic level. The 1978 Act also dealt with non-Olympic amateur sport organizations in the United States including the development of disabled sport organizations (DSOs) that were often defined more by a focus on the type of disability rather than on elite sport development. The USOC also established a Committee on Sport for the Disabled (COSD) in the early 1980s (DePauw \& Gavron, 2005).

The 1978 Amateur Sports Act and 1998 Ted Stevens Amateur Sports Act were significant in moving the United States Olympic Committee (USOC) to be more inclusive by first incorporating key stakeholders in the Paralympic Movement within the United States in the 1980s as represented by a number of fledgling disability governing bodies to a more full integration of the U.S. Paralympic Committee (USPC) as a division of the USOC in 1993. Since the USOC has emerged in the past few years to more fully embrace the Paralympic Games and Paralympic Movement by using its influence to leverage similar adoptions and integration within powerful and key national governing bodies of Olympic and Paralympic sports (USOC, 2011).

\section{Americans With Disabilities Act of 1990}

Enacted by Congress in 1990, the ADA is a comprehensive civil rights law that prohibits, under certain circumstances, discrimination based on disability. It was meant to strengthen and augment the Rehab Act of 1973 by including private organizations as well as public institutions. The ADA was intended to afford similar protections against discrimination to individuals with a disability as the Civil Rights Act of 1964 did in making discrimination based on race, religion, sex, national origin, and other identity characteristics illegal. Although comprehensive in nature, the ADA did not specifically include guidelines relative to participation in sport, recreation and physical activities by individuals with a disability. Most of the case law has instead focused on access to sport facilities and venues related to the rights of the spectator and not from the view of the participants on the field of play (King, 2007).

\section{Ted Stevens Amateur Sports Act of 1998}

In this revision of the original Amateur Sports Act of 1978, Senator Ted Stevens and others opted for changes such as removing the eligibility requirement of being an amateur for being able to compete in most Olympic sports, expanded the role of the United States Olympic Committee USOC's to include responsibil- 
ity for funding and fielding the US Paralympic Team to the Winter and Summer Paralympic Games, increased athlete representation on the USOC Board of Directors, and provided increased protection for the USOC against lawsuits involving an athletes' right to participate in the Olympic Games (codified at 36 U.S.C. Sec. 220501 et seq.).

During this period and leading into the early 1990s, global and national pressure mounted for more equity for athletes based on race, gender and disability. During the late 1980s, national and international sporting events for athletes with disabilities began to be less about cultural games as part of a rehabilitation perspective and more about emerging elite competition The sports movement in the United States during this period was due in part to the motivations and desires of Vietnam War veterans (Disabled Sports USA, 2009). With the passage of the Americans with Disabilities Act of 1990 and the Ted Stevens Olympic and Amateur Sports Act in 1998, athletes with disabilities were hopeful that they would see significant increases with support from the U.S. Olympic Committee (USOC) and other national governing bodies (NGBs) involved in both Olympic and Paralympic sport for participatory and distributive justice issues in sport (ADA, 1990, Ted Stevens, 1998, McArdle, 2009).

Unfortunately, this progression did not occur as new policies from the USOC and its related NGBs pushed for significant regression by limiting resources and sporting opportunities via a stated policy of organization and practical resegregation (Fay, 1999). The decade between 2000 and 2010 has witnessed arguably bigger leaps in the resources, professionalism, legal challenges, and advances in sport technology with regard to sit-skis, prosthetics, sport wheelchairs and related devices than the previous ninety years combined (Zettler, 2009). Athletes such as Marla Runyon, Natalie duToit, Natalia Partyzk and Brian McKeever (all athletes with a disability) have qualified and competed in both Olympic and Paralympic Games (DisabilityNow, 2009).

\section{UN Convention on Human Rights for Persons With a Disability-Article $\mathbf{3 0 . 5}$}

During this last decade, other critical events included the passage and ratification of the U.N. Convention on the Rights for Persons with Disabilities including its landmark Article 30.5 with its focus on sport, leisure and cultural rights for persons with a disability. The recent work of legal scholars are also very relevant to this paper including Janet Lord, partner at BlueLaw International and a Research Associate at the Harvard Law School's Project on Disability, who along with Michael Stein, the Executive Director of Harvard Law School's Project on Disability, co-wrote a seminal article related to the UN Convention on Human Rights for Persons with Disabilities (CRPD) entitled: Social Rights and the Relational Value of the Rights to Participate in Sport, Recreation and Play (Lord \& Stein, 2009). Stein and Lord have also authored a number of other important works related to disability the validity of a social-rights based approach to social justice as promulgated by Jacobus tenBroek and Malcolm Langford (Stein, 2007, Stein \& Lord (2007, 2008, 2009). Lord and Stein lay out a series of key evolutionary steps and frameworks for the purpose of advancing social rights with respect to sport, recreation and play (Lord \& Stein, 2009). 


\section{Maryland Fitness \& Athletic Equity Act}

Stemming out of the McFadden v. Cousin court case of 2006, the state of Maryland subsequently took leadership role with respect to clarifying schools' obligations to provide opportunities in scholastic sports for students with a disability (Lakowski, 2009). This landmark state law requires that schools in the state of Maryland provide students with a disability a number of rights including: a) equal opportunities to participate in physical education and sport programs, b) development of policies and procedures to promote and protect the inclusion of students with disabilities, c) providing reasonable accommodations to include students with disabilities in mainstream programs, d) making adapted programs available to students with disabilities, and e) provide annual reporting to the Maryland State Department of Education detailing their compliance with these requirements (Lakowski, 2009).

\section{CCF-2: A Policy Framework of Selected Legal Cases Dealing with Athletes with a Disability}

In the past ten years, legal scholars have also begun to focus their research on examining and interpreting a new emergent area of case law involving sport and individuals with disabilities. Examples of this development is prominent in the work of Matt Mitten, Moderator for this 2011 Colloquium panel on Disability and Sports and the Director of the National Sports Law Institute and the LL.M. in Sports Law for international lawyers at the Marquette Law School, and panelist and reactor to this paper, Terri Lakowski, who was among those primarily responsible for the pioneering work of the Women's Sports Foundation that has led to need the U.S. Office of Civil Rights to begin to develop new regulations related to athletes with a disability similar to those of Title IX.

Other authors of note that have dealt with the legal environment related to sport and disability issues include Anita Moorman, Professor of Sport Management at the University of Louisville and a contributor to the amicus brief to the US Supreme Court related to the Casey Martin case versus the PGA Tour (2001) and Patricia Zettler,J.D. of Stanford Law, who developed a critical treatise on the implications of technologically innovative prostheses for sports values and rules (Zettler, 2009). These are not the only individuals that should be lauded for their on-going work, as a number of other scholars and legal experts have begun to focus on helping facilitate and support the development of important legal positions that are important to individuals with disabilities in the cases such as:

\section{- Knapp v. Northwestern University (1996)}

This case involved, Chris Knapp, who was medically disqualified based on a heart defect that caused him to have a sudden cardiac death as a high school senior. A recruited, scholarship athlete, Knapp claimed protection under the Rehab of 1973 and the American with Disabilities Act of 1990 that he was being denied the right to a major life activity of playing intercollegiate varsity basketball. This case was important in clarifying issues surrounding medical disqualification, determinants of the definition of disability, and definitions of "otherwise qualified" aspects of the Rehab Act and ADA and the concepts of enhanced risk. To read more on this 
case please refer to Matt Mitten's article in the Marquette Law Journal entitled: Enhanced Risk of Harm to One's Self as a Justification for Exclusion From Athletics (Mitten, 1998).

\section{- PGA Tour, Inc. v. Martin (2001)}

Casey Martin sued and won his right as a professional golfer to be able to compete on the PGA Tour using a motorized cart (Martin v. PGA, 2001, Stone, 2005, and Lakowski, 2009). The Martin case was significant in a number of ways in that it created a new governing framework for resolving disputes involving the rights of athletes with a disability. The Difficulties have arisen, however, in attempting to apply the Martin case across a wide spectrum of situations ranging from youth sport to professional sport. Martin, a professional athlete, argued that he was being harmed from having access to his profession when he was deemed "otherwise qualified" to be able to compete at the highest elite level of professional golf. A number of legal scholars have argued that to apply this standard to amateur sports at the youth and scholastic level is not reasonable due to the fact that school-based athletic programs are educational programs that are an integral part of the student's educational experience and social development. The issue becomes then of one of inclusion (educational model of sport) versus exclusion (professional model of sport). Where the NCAA and its athletic scholarship model of sport fits remains under debate (Lakowski, 2009). To read more on this case please refer to Stone's article in the St. John's Law Review entitled: The Game of Pleasant Diversion: Can We Level the Playing Field for the Disabled Athlete and Maintain the National Pastime, in the Aftermath of PGA Tour v. Martin: An Empirical Study of the Disabled Athlete (Stone, 2005) and Lakowski's article in the Boston University International Law Journal entitled: Athletes with a Disability in School Sports: A Critical Assessment of the State of Sports Opportunities for Students with Disabilities (Lakowski, 2009).

\section{- McFadden v. Cousin, (2006), McFadden v. Grasmick, (2007)}

Tatyana McFadden sued her high school (Athlothon H.S.) and the Maryland Public Secondary Schools Athletic Association (MPSSAA) in 2005 order to gain access to participate on her high school track team. McFadden, a Paralympic wheelchair track athlete and one of the youngest medalists in the history of the Paralympic Game, was not allowed to be on the same track at the same time as other athletes and was forced to race alone as an exhibition event at her high school meets (McFadden v. Cousin, 2006). She subsequently sued the Howard County Public Schools in Maryland District Court and won a preliminary injunction for the right to practice with and compete for her high school track team (McFadden v. Grasmick, 2007). Her points earned, however, would not be scored as part of her team's overall points. McFadden continued her pursuit of justice in the face of on-going discrimination by suing the MPSSAA in 2007 based on the fact the MPSSAA policy "reinforces the stigma of differentness" by creating a segregated scoring system in which McFadden quite literally did not count. To read more on this case and the parallel case of Marie Badgett please refer to Terri Lakowski's article in the Boston University International Law Journal entitled: Athletes with a Disability in School Sports: A Critical Assessment of the State of Sports Opportunities for Students with Disabilities (Lakowski, 2009). 


\section{- Hollonbeck v. USOC (2008)}

Scot Hollonbeck and others sued the U.S. Olympic Committee (USOC) over issues of equity and distributive justice in regard to the disparities between financial support for Olympic athletes versus Paralympic athletes (Hollonbeck v. USOC, 2008, Fay \& Wolff, 2009, Lakowski, 2009). This suit is significant in that, the plaintiffs have used the ADA, Ted Stevens Amateur Sports Act of 1998 and even Title IX as the basis of their arguments for more equity between Olympians and Paralympians. Always an outspoken critic of sport segregation, Hollonbeck competed in 4 Paralympic Games (1992-2004) winning a total of two gold and three silver medals as well as in two Olympic 1500 wheelchair track exhibitions (2000-2004). Hollonbeck, like Tatyana McFadden, faced similar discrimination twenty years earlier as he competed for his Rochelle Township High School (IL) as a member of the school's track and field team. As a sophomore, he was allowed to race in a wheelchair division, but as the only wheeler he often raced in mixed heats with standing runners. His heats were scored separately from the other runners. During his junior and senior years, Hollonbeck was barred from competing in mixed heats with standing runners because of alleged safety issues. In 1987 Hollonbeck filed suit against his school system becoming the first known case in the United States concerning the right for students with a disability to compete on their high school teams. In 1988, a federal judge ruled that his school had violated his civil rights, as provided for under the Rehab Act of 1973. Absent in the case was a ruling on whether high school wheelchair athletes should be able to compete alongside or against their able-bodied peers. In 1988, Hollonbeck, similar to McFadden, received an athletic scholarship the University of Illinois was a member of the school's wheelchair basketball and track and field teams.

\section{- Pistorius v. IAAF (2008)}

Oscar Pistorius is a South African double below-knee amputee sprinter and multiple Paralympic champion who began to also compete in International Association of Athletics Federations (IAAF) international competitions against able-bodied sprinters beginning in 2007. Some felt that his artificial legs, known as Cheetahs, gave him an unfair advantage over able-bodied runners. Also in 2007, the IAAF amended its competition rules to ban the use of "any technical device that incorporates springs, wheels or any other element that provides a user with an advantage over another athlete not using such a device (IAAF, 2007)." With Pistorius's rise to celebrity status as he demonstrated his ability to compete at a near Olympic qualifying level, the IAAF commissioned a series of scientific tests in late 2007 to prove that Pistorius enjoyed considerable advantages over athletes without prosthetic limbs. On the strength of these findings, on 14 January 2008 the IAAF ruled him ineligible for competitions conducted under its rules, which also included the 2008 Summer Olympic Games in Beijing. Pistorius won his administrative appeal in the international Court for Arbitration in Sport (CAS) for the right to compete at the 2008 Beijing Olympic Games (Pistorius v. IAAF, 2008, Fay \& Wolff, 2009, Zettler, 2009). To read more on this case please refer to Patricia Zettler's article in the Boston University International Law Journal entitled: Is It Cheating To Use Cheetahs?: The Implications of Technologically Innovative Prostheses For Sports Values and Rules (Zettler, 2009).

Some of the key considerations in establishing the evidence in a prima facie case of discrimination are: 1) an athlete must establish he/she has a disability; or 2) 
an athlete with a disability is otherwise qualified; or 3) an athlete with a disability is excluded from sport participation solely on the basis of having a disability; or and 4) the is denial of an athlete with a disability was discriminatory because he/she could not be accommodated with reasonable accommodations (Mitten, 1999, Lakowski, 2009). These considerations are further articulated by Matt Mitten in which he described three decision-making models to determine medical discrimination based on: 1) a judicial/medical fact-finding model; or 2) an athlete's "informed consent model; or 3) a team physician medical judgment model (Mitten, 1999).

As an intercollegiate varsity athlete in lacrosse and football from 1967 to 1971, the author was initially allowed to practice under certain restrictions, but prevented from playing in games under the team physician medical judgment model. I then was subsequently allowed to play under restrictions his senior season in football under an athlete's informed consent model. There are also correlations of this type of medical restriction and/or medical discrimination as associated with race and gender in different sports over the past century as imposed by the medical establishment and a various sport governing bodies. A classic example relates to the International Association of Athletics Federations (IAAF) in cooperation with the International Olympic Committee regarding the participation in long distance running races including the marathon. This type of discrimination was finally successfully challenged at the 1984 Los Angeles Olympic Games by Joan Benoit Samuelson, Grete Waitz, Mary Decker Slaney and others (Guttman, 1991, Drinkwater, 2000). Although there can be legitimate concerns of health and safety issues with respect to athletes with certain types of disabilities, these mechanisms can be also used as a means of systematic and institutionalized prejudice and discrimination.

\section{CCF-3: Change in the Level of Influence of High Profile Athletes with a Disability Role Models on Public Opinion}

Many athletes who have a disability face a decision on whether to identify with a sport identity, a cultural identity or both. All persons have multiple identities, whether they participate in sport or not. The higher level of sport competition, the more complex and contextual these multiple identities become. There are many cases of athletes with a disability who are "able" enough (i.e., Zorn, Runyon, Abbott, Robles, et al.) to successfully compete with and against athletes without the same disability or no apparent disability. Where do these athletes fit and how do they define or identify themselves? How athletes answer the basic question of "who am I?" relative to other athletes within a sport context is based on a number of factors including their own awareness and definition of ableism.

The Hall of Fame of NCAA athletes, many of whom were also U.S. Olympic and/or Paralympic athletes, who have significant disabilities and are examples of "otherwise qualified" outliers might be surprising. The following is a sample list along with their sport, position university and Olympic or Paralympic year if relevant.

Wilma Rudolph, Tennessee State University, Track \& Field, 1960 gold medalist 100 and 200 meters. Polio (Guttman, 1991, Wiggins, 2010). 
Trischa Zorn, University of Nebraska, Swimming, 1980 Olympic Trials, 1984 2000 U.S. Paralympic Team, Visually Impaired (DePauw \& Gavron, 2005).

Jeff Float, Stanford University, Swimming, 1984, 1988 Olympic Team, Deaf (http://sportsillustrated.cnn.com/vault/article/magazine/MAG1028489/ index.htm).

Greg Barton, Northern Michigan University, 1984, 1988, 1992 Olympic Team, physical disability in lower limbs (http://www.memphisdowntowner.com/ My2Cents/GregBarton.html

Jim Abbott, University of Michigan, Baseball, 1988 Olympic Team. Physical disability - missing right hand (Abbott, retrieved May 18, 2001).

Nancy Gustafson, University of New Hampshire, Division I - Alpine Skiing, 1988 and 1992 U.S. Paralympic Teams Physical Disability in upper limb. (http://www.paralympic.org/Paralympic_Games/Past_Games/Tignes_ Albertville_1992/index.html).

Marla Runyon, San Diego State University, Track \& Field, 2004, 2008 U.S. Olympic Team, 1996 U.S. Paralympic Team. Visually Impaired (Runyon, 2001).

Neil Parry, San Jose State University, Division I Football. Amputee below the knee (http://sports.espn.go.com/ncf/news/story?id=1619018

Mike Prout, University of Massachusetts - Amherst, Swimming, U.S. Paralympic Team. Physical disability in lower limbs (http://www.umassathletics. com/sports/m-swim/spec-rel/091508aaa.html\#).

Kelly Becherer, Northeastern University, Swimming, U.S. Paralympic Team. Physical disability in lower limbs (http://www.gonu.com/news/2011/4/8/ SWIM_0408115451.aspx)

Anthony Robles, Arizona State University, Wrestling, 2011 NCAA Champion. Physical disability - lower limb (Michoes, 2011).

The above list is meant only to be an illustration and not an exhaustive set of athletes with a disability that competed as intercollegiate athletes. All the athletes listed above are standing athletes who were first good enough to compensate for their particular disability and secondly were able to compete within the rules of their sport to without an accommodation that gave them a unique or unfair advantage. Missing from this list is a number of decorated U.S. Paralympic athletes whose disability is more significant or does not easily allow them to fit within the common rules of the able-bodied version of their sport. Absent are elite athletes who are totally blind or use wheelchairs to perform their sport or sports and who also attended a college or university while they competed at a national or international level.

\section{CCF-4: Change in the Level and Nature of Mainstream Mass Media's Portrayal of High Profile Athletes with a Disability}

Forms of racial and gender intolerance in sport persisted in the United States for most of the 20th century despite the accomplishments of many African-American 
male and female athletes throughout this time (Sage, 1998; Cahn, 1994; Markel et al., 1997; Fay 1999; O’Reilly \& Cahn 2007; Davis, 2008; Wiggins, 2010). These men and women were outliers that succeeded in the face of tremendous odds and prejudice. A half-century ago, an African-American woman, Wilma Rudolph, captivated a nation with her gold-medal performance in the 100- and 200-m sprints at the 1960 Rome Olympics. She did this despite having spent a childhood coping with the challenges of polio (Time, 1960; Guttman, 1991).

It would also be not until the 1984, at the Los Angeles Olympic Games, that the International Olympics Committee would sanction a women's marathon race, the event having long been barred because of prejudice based on medical theories promulgated by male physicians that such an event would do harm to women's health (Drinkwater, 2000, O'Reilly \& Cahn, 2007). 1984 was also the year that the first-ever alpine skiing (Sarajevo) and track exhibition (Los Angeles) events would be held within the Olympic Games for athletes who were amputees in alpine skiing or spinal-injured in track (Legg, et al., 2009). It was also a period of activism and advocacy that resulted in the first national teams being integrated with athletes with disabilities (U.S. Skiing) including equal participation at national championship events (Fay, 1999).

The inclusion of Paralympic exhibition events in track and field introduced for the first time in 1984 with the Los Angeles Summer Olympic Games began a series of summer and winter exhibition events spanning from 1984 to 2008 help illustrate high performance achievement by athletes with a disability through the mass media to a broad global viewership. These exhibition events combined with corresponding breakthroughs in Olympic participation and performances by a range of athletes with a disability (e.g., Fairhall, Abbott, Runyon, du Toit, Partyk, McKeever and others) helped reinforced the concept of Paralympians as high performance athletes (IPC, 2009, Legg, et al., 2009). These track and field exhibition events spanning from Los Angeles in 1984 to Athens in 2004, helped raise the profile of athletes with a disability to a broader national and world public through the means of the broadcast media. These events help encourage a number of Paralympic athletes, coaches, national Paralympic officials and some national Olympic officials to begin to more aggressively advocate that these in track and field events and other sports such as swimming and wheelchair basketball warranted consideration for integration into the Olympic Games with full medal status (Legg, et al., 2009, Brittain, 2010).

Despite the increase in the level and nature of the mainstream broadcast and print media being willing to present the stories and performances of elite athletes with a disability, it took the world media's interest in the 2008 banning by the International Association of Athletics Federations (IAAF) of South African sprinter, Oscar Pistorius, from able-bodied competition to change the level of public awareness involving elite athletes with a disability. Pistorius and his subsequent successful challenge to the IAAF in the Court of Arbitration for Sport in Lausanne, Switzerland later in the Spring of 2008 to be eligible to compete in the Olympic Games in track and field brought to light the complex issues involving athletes with a disability, space age assistive sport technologies and the thresholds of human performance (Zettler, 2009). His story was front page news around the world. Is Oscar the exception or the new rule? Regardless of the success of Pistorius and others, outliers can only pave the way, it takes a critical mass of athletes who compete at a very high 
level over a period of time to be able to sustain any gains in the level and nature of mainstream mass media's portrayal and valuing of athletes with a disability.

\section{CCF-5: Change in the Critical Mass of Athletes with a Disability}

Although the phenomenal accomplishments of gifted outlier athletes are often a critical first step in changing public awareness and attitudes toward a given athlete's identity group (e.g., race, gender, disability), true sustainable change can only come with the establishment of a critical mass of athletes in given identity group who regular attain high athletic achievement and performance. The so-called "outlier effect" is just that a unique, once in a generation emergence of an individual so capable they can overcome all obstacles and perform at an "able-bodied" champion level. With respect to athletes with a disability, these outliers are able to blend into and compete equally with their able-bodied peers with no accommodation given for their respective disability. As a Olympic champion and major league pitcher, Jim Abbott, was able to compensate for the lack of a right hand. This was due in part to his exceptional ability, the sport he chose, and the position he played. Trischa Zorn (swimming), Marla Runyon (distance running) and Brian McKeever (cross country skiing) were all Olympic level performers in their respective sports despite serious visual impairments which labeled them as "legally blind."

Natalie du Toit (distance swimming) and Natalia Partyk (table tennis) competed in both the 2008 Beijing Olympics and Paralympics despite their physical disabilities. Du Toit, who walks with a leg prosthesis, swims without using just her functional stump to propel her through the water. Partyk, like Abbott, who has a disability of the hand and forearm was still able to perform at an Olympic level. In both cases, these athletes were able to adapt under the common rules of their sport without further accommodation. These athletes and others who preceded and will follow them represent once-in-a-generation athlete or outlier.

Not all athletes with a disability are as fortunate to be able to compensate and compete within the mainstream or norm of a given sport. Athletes with multiple physical disabilities, high levels of amputation (legs or arms), total sensory loss (vision or hearing), neurologically impaired athletes and athletes with complete or incomplete spinal injuries face a much more complex environment in gaining access to the sport and physical activity opportunities that their able-bodied or near able-bodied peers take for granted. This comes in the form of a need to adapt the rules of the game (e.g., wheelchair basketball, rugby or goalball) or the assistive technology required to support participation (e.g., racing wheelchairs or handcycles, sit-skis, ice sledges, outriggers for skiing or rowing, sport prostheses) or the assistance of a race guide for an athlete who is significantly visually impaired or blind. In addition, assistance or adaptation of rules might be necessary based on cognitive or intellectual disabilities of the participants.

The athletes in what we will refer to as the "adaptive group" face much greater obstacles and resistance to participate in sport at any level. The following is section briefly outlines the tale of two 22 year old college athletes, each with a different disability, who compete for their respective Division I schools. Anthony Robles, a senior at Arizona State University, is the reigning 125-pound NCAA Division I 
wrestling champion (Michoes, 2011). Tatyana McFadden, a junior at the University of Illinois, is a member of her university's women's wheelchair basketball team and wheelchair track and field team. Although they compete in different sports, each athlete has a significant physical disability in their lower limbs and each is known for their incredible upper body strength. At this point these two stories begin to diverge.

Anthony, who was born with only one leg walks with the use of crutches refusing since his youth to where a prosthesis. When he competes he is at a tremendous disadvantage with respect to being able to execute moves typical to other wrestlers that require the balance and counterbalancing of two legs. Robles makes up for some of this disparity by having strengthened his upper body to a level found in wrestlers in weight classes much higher than the 125 pound division (Michoes, 2011). Given his stunning accomplishments as an intercollegiate wrestler, Anthony would be primed to be considered for a spot on the 2012 U.S. Olympic freestyle team. Although no rule precludes his being eligible to compete for such a position, Robles has decided to retire as an active elite athlete for a career as a motivational speaker. Anthony is not the first outstanding collegiate wrestler with a significant physical disability, however, he is the first All-American $(2009,2010,2011)$, the first NCAA individual champion (2011), the first to be awarded the Outstanding Wrestler of the NCAA Division I Championship Tournament, as well as the first to ever complete an undefeated season (Michoes, March 21, 2011). Anthony's uncommon life story is one of strength, resolve and persistent. His journey to becoming an NCAA champion, however, was a more common one having been a two time state high school champion in his native Arizona.

Tatyana McFadden, was born as an unwanted baby with spina bifida in her native St. Petersburg, Russia. Orphaned until age 6, her condition left her with a hole in her spinal cord and totally paralyzed from the waist down. Tatyana, unlike Anthony, did not have a choice of whether to use a leg prosthesis or a crutches for mobility, her legs simply don't work. She did not even get her first wheelchair for mobility until after her adoption by an American family from Baltimore. Her access point to sports was through the resolve and persistent of her family that sought out opportunities where few existed. Tatyana would become passionate about a variety of sports and physical activities including swimming, wheelchair basketball, scuba diving, downhill skiing, ice sledge hockey, as well as track and field. It was in track and field that she became first known as an elite athlete winning a silver and bronze medal in the 100 and $200 \mathrm{~m}$ respectively as the youngest member of the U.S. Paralympic Track and Field team at the Athens 2004 Summer Paralympic Games (Lakowski, 2009).

Despite having burst unexpectedly onto the world stage as a multiple Paralympic medalist at age 15, Tatyana was not even allowed to practice with her Atholton (MD) High School track and field team. Not willing to accept the prevailing prejudice and discriminatory actions taken against her as an individual with a disability, Tatyana sued for the right to participate with her peers on the Atholton high school varsity track team. In a landmark federal court case, McFadden v. Cousin, Tatyana not only won the right to practice, she also won the right to compete for her high school team. Suing under the American with Disabilities Act of 1990 and the Rehabilitation Act of 1973, McFadden's efforts resulted in the passage of the Maryland Fitness \& Athletic Equity Act (Maryland, Act, 2008) that mandates that 
public schools in the state of Maryland provide full access to sports for students with a disability. This state law has become a model for other states to draw upon in assessing their own practices with regard to the rights of students with disabilities to varsity sports and other common extracurricular activities.

Given her resolve and persistent, Tatyana became a flashpoint regarding her national advocacy for the rights of young people with a disability to have full access to high school sports. At 19, Tatyana returned to compete as a track athlete in the 2008 Beijing Summer Paralympic Games winning 3 silver medals at 200, 400 and $800 \mathrm{~m}$ and a bronze in the relay. After high school, Tatyana was recruited to join the University of Illinois as a member of their nationally acclaimed women's wheelchair basketball and track and field teams. Despite the fact that she is a world renowned athlete and activist who is a multiple Paralympic medalist, McFadden is technically not recognized as a varsity athlete competing in a NCAA sanctioned sport. She and her teammates compete under the aegis as a intercollegiate club sport team. The field of competition include only 11 other colleges and universities (NWBA, 2011).

Thus, the semantics of whether a student-athlete's experience can be appropriately labeled as being a "varsity" intercollegiate athlete do matter. McFadden and her teammates are intercollegiate athletes that are not recognized by either the NCAA or the NAIA and thus they marginalized with respect to their able-bodied peers at the University of Illinois, the Big Ten Conference and the NCAA Division I basketball and track and field Championship Committees. McFadden and her teammates, therefore, face similar prejudice and discrimination at Illinois as she previously faced at Athloton High School. Athletes with disabilities in adaptive sports such as wheelchair basketball and wheelchair track and field are almost completely denied any common access to sport opportunities afforded their able-bodied peers.

For individuals with disabilities, a major paradigm shift required to be able to create a critical mass of athletes with similar disabilities attaining high athletic achievement at the high school and collegiate levels. This presents a glaring need for a systems approach to be able to foster greater integration and inclusion into scholastic and intercollegiate sport for athletes with a disability. Before presenting potential solutions to this situation, it is important to review the realities facing young people with a disability in terms of a sport opportunity spectrum to become "otherwise qualified" as Jim Abbott who was an All-American baseball pitcher at Michigan before his Olympic gold medalist performance in 1988 in Seoul, or Casey Martin being a top NCAA golfer at Stanford or Anthony Robles to participate at the appropriate level of their respective abilities in their chosen sport.

\section{The Sport Opportunity Spectrum}

The Sport Opportunity Spectrum (Fig. 3) is designed to present a typical performance pyramid or ladder of athletic achievement and success. It is intended to demonstrate different levels of qualifications and skills necessary to be able to perform and compete at a given level. The base of the pyramid begins with open, unrestricted opportunities to play up to highly restricted pinnacle of professional and international levels of competition in which only a few athletes qualify and requires tremendous amount of resources to support. The ascent to the top from the left side of the pyramid represents the traditional progression from play to professional/international that includes individuals without disabilities or minimal to no 


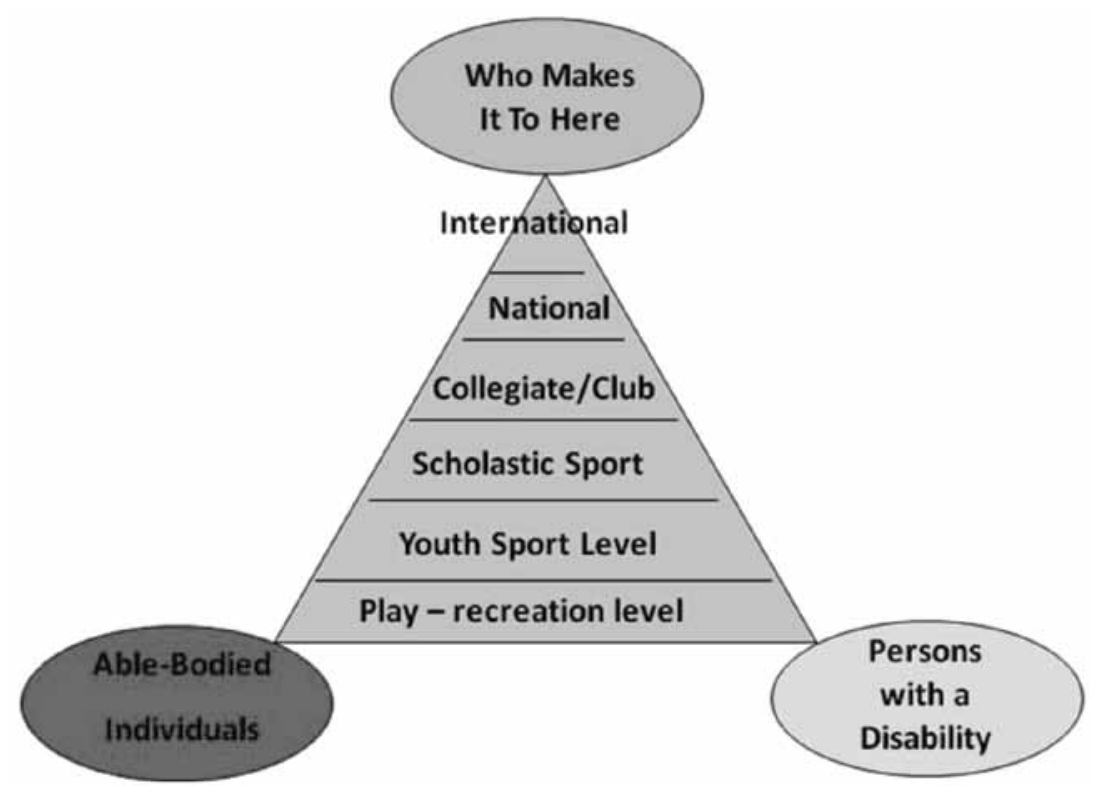

Figure 3 - The Sport Opportunity Spectrum

limiting disabilities. The right hand ascent is meant articulate a potentially different path for individuals with disabilities who might require additional accommodations of specialized equipment (e.g., wheelchairs, ice sledges, hand cycles, golf carts, etc), assistive technology (e.g., prostheses or acoustic devices), a companion such as race guide for athletes with significant visual impairments or a modification in the rules of the sport or event e.g., number of dribbles in wheelchair basketball).

In analyzing the progression up the performance pyramid, it is also important to clarify a framework of disability within specific sport contexts. This is done through the means of the following definitions: a) Mainstream sport defined as sport organized to for persons without a disability, but could include participation by athletes with a disability without accommodation; b) Adapted or disability sport defined as sport organized specifically for persons with a disability; and c) Mixed or unified sport defined as sport organized to intentionally accommodate persons with and without a disability within the same sport context (DePauw \& Gavron, 2005, Lakowski, 2009). These three sport contexts are further defined through a variety of classification systems in sport that are ability classifications based on performance standards versus culture classifications based on a participants disability group (e.g., blind, deaf, amputee, cerebral palsy, spinal injured, etc.). An overarching principle in developing any classification/eligibility system in sport is based on the concept of fair play which attempts to eliminate unfair competition by minimizing unique competitive advantages. Various approaches to creating classification/ eligibility systems in sport include subjectively (phenomenological) systems based on traditions of the sport which may include or more often exclude individuals with a disability (e.g., $P G A$ v. Martin) or attempts by sport governing 
bodies to at least to appear to be interested in creating more objective evidencebased systems (e.g., IAAF v. Pistorius).

A June 2010 report by the U.S. Government Accountability Office (GAO) entitled: Students with Disabilities: More Information and Guidance Could Improve Opportunities in Physical Education and Athletics confirmed what many in the field of adaptive physical education, therapeutic recreation and sport for individuals with disabilities already knew. The results of this national research study found that although certain federal laws help ensure that students with disabilities in kindergarten through 12th grade be provided opportunities to participate in physical education and extracurricular athletics equal to their peers, the data demonstrates otherwise. The gap is particularly significant when it comes to extracurricular scholastic sports (GAO, 2010). Some of the data from the GAO study and other sources reveal that:

- $56 \%$ of people with disabilities do not engage in any physical activity, compared with $36 \%$ of people without disabilities

- Only $23 \%$ of people with disabilities are active for $30 \mathrm{~min}$ three or more times per week.

- There are nearly 1.5 million $\mathrm{K}-12$ graders in the United States with physical impairments that are not included in athletic competitions.

- The National Federation of State High School Associations (NFSHSA) does not address participation of individuals with disabilities, but leaves this issue to the discretion of each of the respective 50 state associations

- The NCAA does not officially sanction any varsity intercollegiate program, event or competition or Championship for individuals with disabilities

- The 2008 Summer Paralympic Games had 1/3 of the level of participation of athletes with disabilities as did the 2008 Olympic Games of athletes without disabilities

In essence, youth with disabilities between ages 6-22 have disproportionately fewer opportunities to participate in scholastic and/or intercollegiate varsity sports and thus there is a major hole in the rungs of the performance latter at those levels. One of the GAO's recommendations from the 2010 study is to improve the opportunities for students with disabilities in PE and athletics and the study recommends that the U.S. Secretary of Education through its Office on Civil Rights facilitate information sharing among states and schools on ways to improve opportunities and clarify institutional/school responsibilities under federal law. One such option would be to create regulations similar to those crafted by the OCR for Title IX.

To that end, Alliance for Athletics Equity for Students with Disabilities in partnership with the University Center for Excellence in Developmental Disabilities at Georgetown University is hosting the Physical Activity and Sport for People with Disabilities Symposium and Strategic Planning meeting June 21-22, 2011. The purpose of the symposium and strategic planning meeting is intended to bring key stakeholders together to create a community blueprint for action in response to the forthcoming policy recommendations from the Department of Education Office on Civil Rights. One of the efforts at this symposium will be to extend the focus on 
$\mathrm{K}-12$ schools to also include colleges and universities that receive federal funds and are therefore subject to Title IX

The following is an exercise of a series of questions that would have radically different responses depending on whether the identity (ID) group is based on race, gender or disability. These questions have been adapted from a Women's Sports Foundation training program that focuses on the rights of girls and young women in scholastic and university sport environments by substituting the word "girl or woman" for individuals with a disability (Lakowski, 2009).

\section{Know Your Rights: From Title IX-A to Title IX-B}

1) Can colleges or universities deny individuals with disabilities the right to participate in its varsity athletic programs based on safety concerns if the athlete is otherwise qualified?

2) Must a college or university include a student with a disability on mainstream, adapted or allied teams if she or he does not have sufficient skills to compete even with reasonable accommodations?

3) Do the standard rules governing athletic participant eligibility (i.e., GPA, age) apply to students with disabilities who are competent enough to warrant an athletic scholarship?

4) Can colleges and universities refer students with disabilities to communitybased adapted sports programs as a way to meet their obligations under the Rehab Act of 1973, ADA or a new law similar to Title IX?

5) If not, how would colleges and universities fulfill their obligations to create adapted teams when the numbers of students with disabilities at an individual school are insufficient to field a team?

6) Should intercollegiate teams for students with disabilities be separated by sex? How would institutions deal with the issue of mixed sex teams for studentathletes without a disability?

7) Can schools or universities deny individuals with disabilities the right to use competition and training facilities due to concerns about equipment (wheelchair, prostheses) damaging playing surfaces?

8) In individual sports, should events for individuals with disabilities be awarded points in the same manner as events for individuals without disabilities such as in dual meets, league or NCAA Championships?

9) Do prostheses provide an unfair advantage in competition such as in track and field as based on the findings related to South African sprinter Oscar Pistorius (Zettler, 2009)?

In relating this sport opportunity spectrum back to Anthony Robles and Tatyana McFadden, ironically Anthony's experience was more traditional and therefore moved up the left side of the ladder, while Tatyana's was quite different and is a prime example to the lack of opportunities as represented by ascending up the right side of the ladder and her basically being forced to skip the scholastic and intercollegiate and go directly to international as a 15 and 19 year Paralympic medalist. According to Ken Blanchard and Norman Vincent Peale in their treatise: The Power 
of Ethical Management (1988, p. 9), there is "no right way to do a wrong thing!" Leaders who enforce the status quo and the prevailing cultural hegemony, also are in a position to make decisions that can change and revise decades and centuries of prejudice and discrimination.

\section{CCF-6: Change in the Attitudes of Key Leaders in Sport Power Elites Who Act as Catalysts for Breakthroughs}

The history of social rights movements and their efforts to change the prevailing hegemony of power and/or ruling elites, shows that the particular identity group (e.g., race, sex, disability, faith, sexual orientation, etc) must have strategic allies that come from the power elites who act as catalysts for breakthroughs in gaining greater integration and inclusion (Fay, 1999, Fay \& Wolff, 2009). Who are such leaders who would need to be educated and then convinced to support serious change? High School Athletic Associations in less than 10 states and fewer than 15 colleges and universities offer adaptive varsity sport programs for students with disabilities and none are under the auspices of the NCAA or compete for an NCAA Championship.

The strategic leadership must come from the following set of scholastic and collegiate governance systems that include: a) National Federation of State High School Associations (NFSHSA); b) 50 State High School Athletic Associations; c) the National Junior Collegiate Athletic Association (NJCAA) and its member institutions; d) the National Association of Intercollegiate Athletics (NAIA) and its XX member institutions; and e) the National Collegiate Athletic Association (NCAA) and its 1,300 NCAA Member Institutions in 3 Divisions (I, II, and III). The NCAA purports to have over 400,000 student- athletes competing in affiliated leagues and conferences for the right to participate in 88 NCAA Championships in 23 sports (ncaa.org). The key stakeholders who need to be further educated and influenced to become strategic allies for change include NCAA President, Mark Emmert; the college presidents and athletic directors of 1300 NCAA member institutions, along with league and conference Executive Directors.

In the process of advocating for new integration and inclusion of intercollegiate student-athletes with a disability means adding to the 400,000 current athletes and 88 NCAA Championships in 23 sports one needs to review the NCAA's core values and its core purpose to see if it prohibits or precludes the these athletes. The following from the NCAA official website (ncaa.org) states:

\section{NCAA Mission-Core Values}

1) The Association - through its member institutions, conferences and national office staff-shares a belief in and commitment to:

2) The collegiate model of athletics in which students participate as an avocation, balancing their academic, social and athletics experiences.

3) The highest levels of integrity and sportsmanship.

4) The pursuit of excellence in both academics and athletics. 
5) The supporting role that intercollegiate athletics plays in the higher education mission and in enhancing the sense of community and strengthening the identity of member institutions.

6) An inclusive culture that fosters equitable participation for student-athletes and career opportunities for coaches and administrators from diverse backgrounds.

7) Respect for institutional autonomy and philosophical differences.

8) Presidential leadership of intercollegiate athletics at the campus, conference and national levels.

\section{NCAA Mission-Core Purpose}

Our purpose is to govern competition in a fair, safe, equitable and sportsmanlike manner, and to integrate intercollegiate athletics into higher education so that the educational experience of the student-athlete is paramount. The Associationthrough its member institutions, conferences and national office staff-shares a belief in and commitment to:

9) The collegiate model of athletics in which students participate as an avocation, balancing their academic, social and athletics experiences.

10) The highest levels of integrity and sportsmanship.

11) The pursuit of excellence in both academics and athletics

12) The supporting role that intercollegiate athletics plays in the higher education mission and in enhancing the sense of community and strengthening the identity of member institutions.

13) An inclusive culture that fosters equitable participation for student-athletes and career opportunities for coaches and administrators from diverse backgrounds.

14) Respect for institutional autonomy and philosophical differences.

15) Presidential leadership of intercollegiate athletics at the campus, conference and national levels.

The 15 core values and elements related to purpose reflect the appearance of an inclusive member-driven body. If fact, the 6th core value states: "An inclusive culture that fosters equitable participation for student-athletes and career opportunities for coaches and administrators from diverse backgrounds (ncaa.org)." Perhaps a starting point would be for NCAA President Emmert to convene the 15 presidents and athletic directors from the colleges and universities that support one or more intercollegiate sport for athletes with a disability. Perhaps using the 2010 GAO Report as a template, the NCAA and participating member institutions could extend the existing data on $\mathrm{K}-12$ schools to the NCAA membership to see where there might be the interest in expanding sport opportunities for students with a disability. If just $10 \%$ of NCAA members agreed to add one or two additional sports this would mean a 100 fold increase in opportunities from 15 to 150 institutions which would be an average of 3 colleges or universities per state. To do so, however, there needs to be mechanisms to chart such progress that compiles with federal law and any new regulations that might be implemented through the U.S. Department of Education in the form of a Title IX - B for athletes with a disability. 


\section{Organizational Continuum-Ableism in Sport}

The following organizational continuum is (Fig. 4) presented as a means to measure and assess such a breakthrough in the rights and opportunities for athletes with a disability at the scholastic and intercollegiate levels. This conceptual framework works as an "access" paradigm that shows where a person or group resides within a dynamic organizational environment based on a self or culturally imposed identity group label such as race, gender, disability, sexual orientation, faith, or other identity characteristic.

This construct was modified by the author in 1999 from a model originally developed from research on workplace diversity by Esty, Griffen and Hirsch (Esty, et al., 1995). The Organizational Continuum on Workplace Diversity was a unidirectional model that did not account for stratification levels of different types of employees (i.e., labor, management and ownership). Fay adapted and modified this model by incorporating Sage's stratification levels and representing this continuum as a dynamic environment that may be progressive, regressive or static, ranging from exclusivity for a particular identity group (e.g., white males) to inclusivity embracing a wide spectrum of identity groups (Sage, 1998). This continuum helps map the progression of a given identity group within the context of time and place. It also allows one to discover that an organization might be more progressive regarding the utilization and integration of labor and less progressive in the levels of management, and ownership (Fay, 1999, 2009).

One of the biggest fears that groups in power have in sharing power or incorporating new identity groups into their organization is one of economic resources. Similar to the on-going equity battles associated with issues related to the integration and inclusion of women into the NCAA and intercollegiate sport since the enactment of Title IX in 1972, fears exist that existing resources that are currently prioritized and given to able-bodied athletes might be somehow diverted to athletes with a disability. This belief system serves to perpetuate myths and stereotypes as to who should get to participate at certain levels of sport and who should not

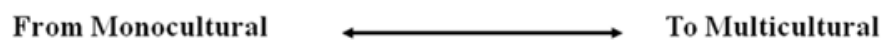

\begin{tabular}{|l|l|l|l|l|l|}
\hline EC & LSI & T & CM & TAD & VD \\
\hline
\end{tabular}

Exclusive Organization

Inclusive Organization

- Exclusive Club (EC)

- Lip Service to Inclusion (LSI)

- Tokenism (T)
- Critical Mass (CM)

- Tolerating/Accepting

Diversity (TAD)

- Valuing Diversity (VD)

Figure 4 - Organizational Continuum (Racism, Sexism \& Ableism) 
(Hollonbeck v. USOC, 2008). These perceptions and attitudes is often more due to a lack of awareness, education and expertise on the part of management professionals within sport governance structures in fully understanding the capability and level of athletic ability of a person with a disability.

"Inclusion" has been defined in the context of UN Convention on Human Rights for Persons with a Disability (CRPD) as the final stage of integration of people with disabilities in sport competition or a sport organization in which they are involved, accepted and respected at all levels of the competition, and/or organization or governing body (Lord \& Stein, 2009). For purposes of this article, integration through increased access to opportunities becomes significant at Stage IV-Critical Mass with an environment of inclusion based on integrity and respect emerging at Stage V. Power being gained by a given identity group begins to be identified primarily in Stage VI (Esty, et al., 1995, Fay, 1999; Fay \& Wolff, 2009). Barriers to inclusion stubbornly remain due to a number of factors including: a) able-bodied sport as the norm in a given society; b) sport and leisure activities for people with disabilities has a diminished value; c) prioritization of economic resources is most often given to able-bodied sport; d) sport organizations remain unaware of rights and needs through a lack education and expertise; and e) classification and eligibility systems in adaptive sport is complicated and costly.

Drawing upon the CCFM and Organizational Continuum in Sport Governance (OCSG) frameworks, Eli Wolff reflected in 2000 on the need to be more critical and comprehensive in analyzing the qualitative context and meaning of the movement of an identity group (e.g., race, gender or disability) from one stage on the OCSG to the next one. He drew in part upon his own experiences as a collegiate athlete at Brown University and Paralympic soccer athlete for the U.S. Paralympic Team (Wolff, 2000). In 2008, Fay and Wolff modified the Criteria for Inclusion framework by intersecting the six stages of the OCSG model with the nine elements of criteria for inclusion (Fig. 5). This allows the assessment and grading of the efforts of a particular organization or governance system such as the NCAA, a NCAA member institution, state high school federation or a local high school with respect to each element of the framework.

Thus, an organization that clearly acts and maintains its practices as an exclusive club (Stage I of the OCSG) such as the NCAA would have a score between 9 and 17 , whereas if it were to progress to Stage II by showing lip service to inclusion, it would have a score between 18 and 26. This framework could be used to assess the effectiveness in adopting the requirements of Title IX, the requirements of the Rehab Act of 1993, the Americans with Disabilities Act of 1990, Article 30.5 of the UN Convention on the Rights of Persons with Disabilities (United Nations, 2007) or a state law such as the Maryland Fitness \& Athletic Equity Act (Maryland, Act, 2008).

Using these conceptual frameworks, one could begin to quantify and compare NCAA institutions such as the University of Illinois at Champaign-Urbana and the University of Texas-Arlington with other institutions in their respective states and/or NCAA sport conferences with respect to their efforts toward integration and inclusion of athletes with a disability as scholarship supported varsity athletes. The eleven institutions listed in Figure 6.

In each instance, these institutions have reached at least Stage IV-Critical Mass and potentially Stage V-Tolerating and Accepting Diversity in their progression from a monoculture of sponsoring only able-bodied varsity athletes and 


\begin{tabular}{lcccccc} 
& \multicolumn{7}{c}{ OCSG Stages } \\
& EC & LSI & T & CM & TAD VD \\
CI - 1: Governance (Mission and Policies) & 1 & 2 & 3 & 4 & 5 & 6 \\
CI - 2: Media and Information Distribution & 1 & 2 & 3 & 4 & 5 & 6 \\
CI - 3: Management & 1 & 2 & 3 & 4 & 5 & 6 \\
CI - 4: Funding and Sponsorship & 1 & 2 & 3 & 4 & 5 & 6 \\
CI - 5: Awareness and Education & 1 & 2 & 3 & 4 & 5 & 6 \\
CI - 6: Events and Programs & 1 & 2 & 3 & 4 & 5 & 6 \\
CI - 7: Awards and Recognition & 1 & 2 & 3 & 4 & 5 & 6 \\
CI - 8: Philosophy & 1 & 2 & 3 & 4 & 5 & 6 \\
CI - 9: Advocacy & 1 & 2 & 3 & 4 & 5 & 6
\end{tabular}

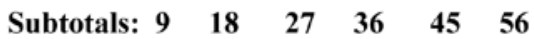

(Reflects each stratification level and each stage of Organizational Continuum)

Figure 5 - Criteria for Inclusion

Intercollegiate Wheelchair Basketball

University of Arizona

Edinboro University (PA)

Kennesaw State University (GA)

University of Missouri

University of Texas at Arlington

Ohio State University

Southwest Minnesota State University

University of West Georgia

University of Alabama at Tuscaloosa

University of Wisconsin at Whitewater

University of Illinois at Urbana - Champaign

(Lakowski, 2009)

Figure 6 - Intercollegiate Wheelchair Basketball

teams to a multicultural model of including adaptive sport teams with individuals with disabilities within their domain of varsity intercollegiate sport.

\section{Conclusion: Diverse Sport Opportunities for People with Disabilities}

This brings us to the present and a new window to the future. To contextualize where we have been, where we are and how far we have yet to go to realize a nation and a world that celebrates and values diversity, we must ask what the next 
decade (2019), quarter century (2034), half century (2059) or century (2109) will yield. Will the high school, NCAA, world and Olympic champions of the future look more like Anthony Robles, Tatyana McFadden, Oscar Pistorius and less like intercollegiate and Olympic athletes of the present? Will there be a shift from the "norms of naturalism" to transhumanism that will yield new paradigms and understanding of what is sport and who are athletes?

In analyzing the societal change process, one must consider whether it is a series of random events or if it can be viewed as a more strategic and therefore intentional process. As Malcolm Gladwell illustrated in his book, The Tipping Point, social phenomena and systems change defy linear or incremental analysis and reasoning (Galdwell, 2002). Instead, change is often a blend of weighted factors or variables (CCF 1-10) that come together in a "perfect storm-like" concussion that precipitates major cultural shifts in societies as they become either more or less inclusive.

Part of the purpose of the keynote speech and this companion article has been to add new discourse (the third leg of the stool) by involving the concepts of ableism in challenging the hegemony of sport power elites similar to those that perpetuate racism and sexism as found in sport and in society. Work in all sectors needs to help advance access, inclusion, equality, respect, legitimacy and opportunity for people with disabilities in sport and in society. Through research (e.g., GAO study), education and advocacy activities, the invisibility of people with disabilities in an effort to construct new and diverse sport opportunities within existing mainstream systems of sport ranging from interscholastic and intercollegiate systems in the United States and Canada to the more common sport club system found in other parts of the world.

Initiatives need to be developed and brought to sport governing organizations and their member institutions such as the NCAA that bring people with disabilities from the margins to become integral members of the sporting community. Ongoing research needs to be conducted examining the inclusion of people with a disability in sport through the auspices of sport governing systems such as state high school federations and intercollegiate leagues and conferences. Agencies from both the public and private sectors need to serve as facilitators to organize and bring individuals and groups to work together to promote the inclusion of people with disabilities (Fay \& Wolff, 2010).

Individuals and organizations such as the NCAA need to continually work on integrating people with disabilities from the margins of society into their desired sporting communities. Ongoing research needs to examine ways to facilitate and support the full inclusion of people with disabilities in sport. This research must be practiced through conscious reflection and evidence-based qualitative and quantitative analyses of the past and present to create arguments for systems change for the future. Sport technology will force the reconceptualization of the Sport Opportunity Spectrum in relation to new classification systems that reduce and end marginalization as the status quo while promoting legitimatization as the new inclusive paradigm.

A "Triple A" strategy of athletes, advocates and strategic allies is needed to help break down barriers and reduce the fear factor present in the change toward a more inclusive and equitable society. We need personal narratives of pathfinders such as Trischa Zorn, Jim Abbott, Scot Hollonbeck, Anthony Robles, Oscar Pistorius and Tatyana McFadden who have waged their own struggle to help frame the 
contest and create a game plan to illustrate how to effect change for greater equity and justice. Finally, we may have to be willing to break the rules of the game to create greater access to the fields of dreams. What will be the Sport Opportunity Spectrums for athletes with a disability in intercollegiate athletics in the next fifty years? What will be the sport social justice legacy of this generation?

The time has come to move from an environment of endless recommendations to an era of new regulations that hold similar same elements of equity found in Title IX for athletes with a disability. Access to opportunities for individuals with disabilities to be able to play (love), practice (learn), participate (engage), perform (demonstrate), and perfect (master) is not a privilege, it is a social right (CPRD, 2007)! Now is the time, to get "it" right!" It is the moment to begin the shift from the sidelines to the frontlines. Join us, the Alliance for Athletics Equity for Students with Disabilities, in lobbying for the establishment of new national regulations promulgated through the U.S. Department of Education Office on Civil Rights for a National Fitness and Athletic Equity Act that connects the sport context and regulations of Title IX to the Rehab Act of 1973! We need to create a Title IX-B for individuals with disabilities.

\section{References}

Americans with Disabilities Act of 1990, Pub. L. 101-336, 104 Stat. 327 (codified in scattered sections of 42 U.S.C.).

Blanchard, K., \& Peale, N.V. (1988). The power of ethical management. New York: HarperCollins.

Brittain, I. (2010). The Paralympics Games explained. London: Routledge.

Cahn, S. (1994). Coming on strong: Gender and sexuality in twentieth-century women's sport. New York: Free Press.

Civil Rights Act of 1964, Pub. L. 88 - 352, 78 Stat. 241 (July 2, 1964).

Coakley, J. (2008). Sport in society: Issues \& controversies (10th ed.). Boston, MA: McGraw Hill.

Convention on the Rights of Persons with Disabilities, G.A. Res. 61/106, U.N.Doc. A/ RES/61/106 (Jan. 24, 2007).

Davis, T. (2008). Race and Sports in America: An Historical Overview, 7 VA.

DePauw, K.P., \& Gavron, S.J. (2005). Disability sport (2nd ed.). Champaign, IL: Human Kinetics Publishers.

DisabilityNow. (2009). Games without frontiers, available at http://www.disabilitynow.org. uk/living/ features/games-without-frontiers

Drinkwater, B.L. (Ed.). (2000). Women in sport. Lausanne, SUI: IOC Medical Commission Sub-Commission on Publications.

Esty, K., Griffen, R., \& Hirsch, M.S. (1995). Workplace diversity: A manager's guide to solving problems and turning diversity into a competitive advantage. Avon, MA: Adams Publishing.

Fay, T.G. (1999). Race, gender, and disability: A new paradigm towards full participation and equal opportunity in sport. Doctoral dissertation. University of Massachusetts Amherst.

Fay, T.G. (2009). Disability and Technology: Innovation and the Ethics of Inclusion. Power of Sport Summit 2009: Sport and Social Responsibility, Center for the Study of Sport in Society, Northeastern University, Boston, MA, June 18 - 19, 2009.

Fay, T.G. (2005, October). Racism, Sexism \& Ableism in Sport. North American Society for the Sociology of Sport (NASSS) Annual Conference, Winston-Salem, NC. October 27, 2005. 
Fay, T. G. \& Wolff, E. A. (2009 Summer). Disability in Sport in the Twenty-First Century: Creating a New Sport Opportunity Spectrum. Boston University International Law Journal. 27, 2. pp. 231 - 248.

Fay, T.G., \& Wolff, E.A. (2010). Disability in Sport: Applying the Opportunity Spectrum. International Conference on Sport and Society, Vancouver, BC. March 10, 2010.

Fay, T.G., \& Wolff, E.A. (2004, June). Policy implications of Hollenback, et al v. USOC on National Branding Efforts of the US Paralympics, Inc: Confusion, conflict, compromise or court?" North American Society for Sport Management (NASSM) Annual Conference, Atlanta, GA. June 2 - 5, 2004.

Galdwell, M. (2002). The tipping point: How little things can make a big difference. New York: Little, Brown \& Co.

Guttman, A. (1991). Women's sports: A history. New York: Columbia University Press.

Hehir, T. (2002). Eliminating ableism in education, Harvard Education Review. 72, pp. 1, 3. Hollonbeck v. U.S. Olympic Committee. 513 F.3d 1191. 1194-96 (10th Cir. 2008).

http://sports.espn.go.com/ncf/news/story?id=1619018

http://www.jimabbott.net/biography.html

http://www.gonu.com/news/2011/4/8/SWIM_0408115451.aspx

http://www.memphisdowntowner.com/My2Cents/GregBarton.html

http://sportsillustrated.cnn.com/vault/article/magazine/MAG1028489/index.htm

http://www.umassathletics.com/sports/m-swim/spec-rel/091508aaa.html\#_

http://www.womenssportsfoundation.org/Content/Articles/Issues/Title-IX/U/Understandingthe-Amateur-Sports-Act.aspx\#

King, B. (July 9 - 15, 2007). Equal access: Americans with disabilities special report. Sports Business Journal. 10, 11, pp. 1, $17-22$.

Lakowski, T. (2009 Summer). Athletes with a Disability in School Sports: A Critical Assessment of the State of Sports Opportunities for Students with Disabilities. Boston University International Law Journal. 27, 2. pp. 283 - 31.

Legg, D., Fay, T.G., Hums, M.A., \& Wolff, E.A. (2009). Examining the inclusion of wheelchair exhibition events within the Olympic Games 1984 - 2004. European Sport Management Quarterly, 9, 3.

Lord, J.E.. \& Stein, M. A. (2009 Summer). Social Rights and the Relational Value of the Rights to Participate in Sport, Recreation and Play. Boston University International Law Journal. 27, 2. pp. 249 - 281.

Lovett, C. (1997). Olympic Marathon: A centennial history of the Games'most storied race. available at http://www.marathonguide.com/history/olympicmarathons/chapter25.cfm.

Mackelprang, R. W. \& Salsgiver, R. O. (1998). Disability: A diversity model. Approach in Human Service Practice, 4.

Markel, R., Waggoner, S., \& Smith, M. (1997). The women's sports encyclopedia: The comprehensive guide to women's sports, women athletes \& their records. New York: Henry Holt \& Co.

McArdle, D. (2009 Summer). Using the American with Disabilities Act to Inform "Access to Sporting Venues" Under Disabilities Convention. Boston University International Law Journal. 27, 2. pp. 317 - 344.

Michoes, G. (2011 March). Born with one leg, Arizona State wrestler wins NCAA title, USA Today, March 21, 2011.

Mitten, M. (1998). Enhanced risk of harm to one's self as justification for exclusion from athletics. Marquette Sports Law Journal, 8, 189.

O'Reilly, J., \& Cahn, S. (2007). Women and sports in the United States. Hanover, NH: University Press of New England.

McFadden v. Cousin, No. AMD 06-648 (D. Md. Apr. 17, 2006).

PGA Tour, Inc. v. Martin, 532 U.S 661, 666-67 (2001).

Pistorius v. International Amateur Athletics Federation, CAS 2008/A/1480, at 7-8 (May $16,2008)$. 
Plessy v. Ferguson, 163 U.S 537, 539 (1896).

Runyon, M., \& Jenkins, S. (2001). No finish line: My life as I see it. New York: Penguin Publishing.

Sage, G.H. (1998). Power and Ideology in American Sport: A critical Perspective (2nd ed., pp. 59). Champaign, IL: Human Kinetics Publishers.

Stone, D. H. (2005). The game of pleasant diversion: Can we level the playing field for the disabled athlete and maintain the National Pastime, in the aftermath of PGA Tour, Inc. v. Martin: An empirical study of the disabled athlete, 79 St. John's L. REV. $377-387$.

Ted Stevens Olympic and Amateur Sports Act, 36 U.S.C. $§ 220501$ et seq. (2000).

(1979). Title IX Educational Reform Act of 1972. A Policy Interpretation: Title IX and Intercollegiate Athletics. 44 Fed. Reg., 71413, 71418.

Time (1960 September). The Fastest Female. Sept. 16, 1960, Retrieved at http://www.time. com/time/magazine/article/0,9171,826652,00.html.

Wiggins, D. (Ed.). (2010). Sport in America: From colonial leisure to celebrity figures and globalization. Champaign, IL: Human Kinetics Publishers.

Wolff, E.A., Hums, M.A., \& Fay, T.G. (2005 October). Fear Factor: Fear of Disability and the Unspoken Reality. North American Society for the Sociology of Sport (NASSS) Annual Conference, Winston-Salem, NC. October 27, 2005.

Zettler, P.J. (2009). Is it Cheating to Use Cheetahs?: The Implications of Technologically Innovative Prostheses for Sports Value and Rules. Boston University International Law Journal, 27(2), 367-409. 